\title{
頭頸部手術における創縫合器の使用経験
}

\author{
今手 祐二1) - 遠藤 史郎 $11 \cdot$ 緒方 道彦1) - 蓮池 耕二1) \\ 高橋 正紘 ${ }^{1)}$-日吉 正明2) - 緒方 正彦2) - 守谷 啓司 ${ }^{3)}$
}

\section{Advantages of Using a Skin Stapler in Head and Neck Surgery}

\author{
Yuji Imate, Shiro Endo, Michihiko Ogata \\ Kouji Hasuike and Masahiro Takahashi \\ (Yamaguchi University) \\ Masaaki Hiyoshi and Masahiko Ogata \\ (Yamaguchi Central Hospital) \\ Keiji Moriya \\ (Nagato General Hospital)
}

\begin{abstract}
In 12 cases of head and neck surgery, use of a disposable skin stapler (Proximate ${ }^{\circledR}$ Ethicon) was compared with nylon sutures with respect to time required for wound closure and the cosmetic result. Time required for closure was reduced by $90 \%$ using the stapling device, and cosmetic appearance was satisfactory compared to that with nylon sutures. With regard to safety, we found that the staples were not exposed into the subcutaneous space when subcuticular suture was performed. It was concluded that stapling is satisfactory in head and neck surgery with regard to safety and cosmetic results.
\end{abstract}

Key words : skin stapler, wound closure, time, safety, cosmetic result

はじめに

最近，頭頸部手術はマイクロサージェリーの導入や， 両頸部郭清の適応例の増大などにより, 手術に10数時間 を要することも稀ではない，手術時間の短縮も大きな課 題と考えられるが，本来の手術そのものの時間短縮は容 易ではない，手術全体の中でかなりの時間を要する最後 の創縫合の時間短縮を目的として, 簡便な皮膚縫合器で あるスキンステイプラーの頭頸部領域への導入を試みた。

\section{方法}

ステイプラー (Proximate ${ }^{\circledR}$; Ethicon) 扎よびステイ プルの抜去に使用するリムーバーを図 1 上段に示す。ス
テイプルはレギュラーサイズ $(5.7 \mathrm{~mm} \times 3.9 \mathrm{~mm})$ (図 1 下段) とワイドサイズ $(6.9 \mathrm{~mm} \times 3.9 \mathrm{~mm})$ があり, 通常 皮下脂肪に富む領域ではワイドサイズが用いられるが， 今回頭頸部領域に怙いてはレギュラーサイズを使用した 使用方法は有鈎鑷子にて創縁を翻転し合わせた後，ステ イプラーを軽く接触させステイプルを刺入する。

\section{検討項目}

創縫合に要する時間を計測し，従来のナイロン系によ る縫合時間と比較した. 創の美容面に関しては, 術後約 1 カ月の時点の創の美しさを肉眼的に観察評価した. 安 全面では，頸部皮膚の厚さを計測，皮下縫合の有無によ

1) 山口大学医学部耳鼻咽喉科学教室

2) 山口県立中央病院耳鼻咽喉科

3）長門総合病院耳鼻咽喉科 

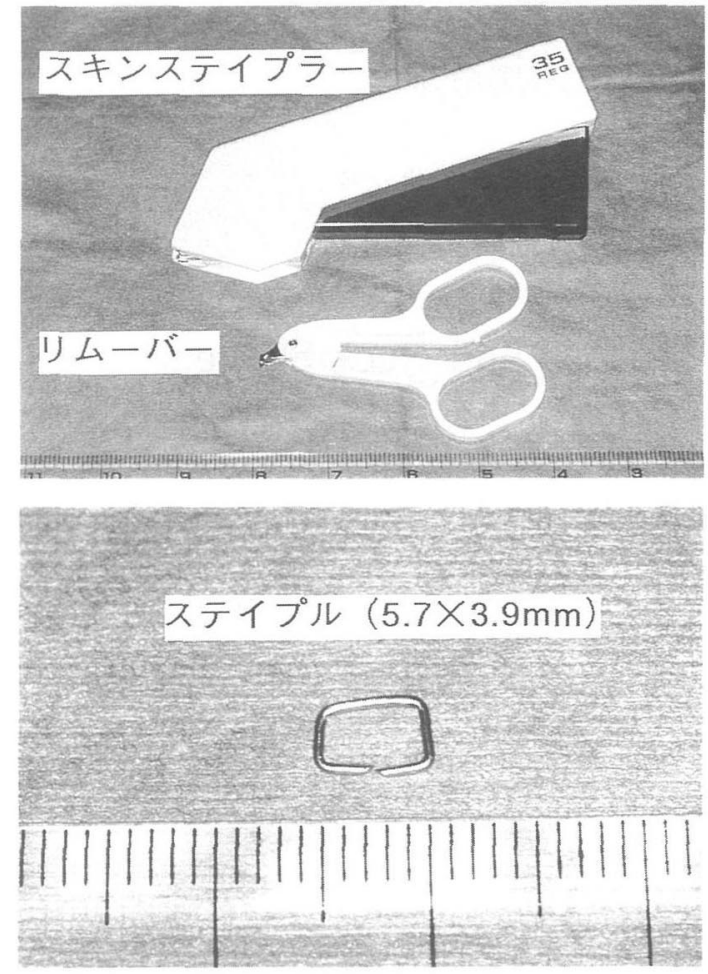

図1スキンステイプラー, リムーバー, ステイプル

る違いを検討した。

\section{対 象}

対象は1994年 2 月より 6 月までの間に当科の頭頸部手 術に执いてスキンステイプラーを用いた12症例(表 1 )で ある.12例中 9 例に両頸部郭清を行い，U字または両側 Y字の皮膚切開を用いた。

\section{結果}

今回の対象症例のうち両頸部郭清施行例で $U$ 字または
両側 $Y$ 字切開の縫合線の長さ，皮下縫合招よび皮膚縫合 に要した時間を計測した。スキンステイプラーを用いた 場合の皮膚縫合時間は $10 \mathrm{~cm}$ の長さを縫合するのに約 1 分弱であった(表 2$) 、 今$ 回スキンステイプラーを用い たため，通常のナイロン系による縫合は行っていないが， 経験的には皮膚縫合時間は皮下縫合時間上りやや短めで ある、スキンステイプラーによる縫合で皮膚縫合時間は 約 $1 / 10$ 飞短縮された.

美容面については, 代表例として下咽頭腫瘍でU字切 開, 雨頸部郭清後遊離空腸による再建を行った症例の創 の状態を，経時的に観察した。術後 1 週 (図 2 )のステイ プル拔去直後にはステイプル自体の刺入痕が目立つが, 術後 2 週(図 2 )では創もきれいになり, 術後 4 週(図 2 ) ではナイロン系による縫合とほとんど差を認めなかった。 表 3 は今回ステイプラーを使用した12症例の術後約 1 カ 月の縫合創の状態の観察結果である.いずれの症例に抒 いても創の状態は良好であった。

安全面に関して頸部は重要な血管や神経があり, 頸部 郭清を行った症例ではそれらが皮下に露出するので, 特 に安全面の確認が必要之思われる。ステイプラー使用時

婊 2 切開線の長さ之縫合時間

両頸部郭清症例

\begin{tabular}{l|c|c}
\hline \hline 皮膚切開 & $U$ 字切開 & 両側Y字切開 \\
\hline & 35 & 45 \\
\hline 切開線の長さ (cm) & 35 & 55 \\
\hline 皮下縫合時間(分) & 40 & 4
\end{tabular}

表 1 対象症例

\begin{tabular}{|c|c|c|c|}
\hline 断 & 手 & 皮 & 症例数 \\
\hline 下咽頭腫瘍 & $\begin{array}{l}\text { 咽·喉·食摘出+両頸部郭清 } \\
\text { +遊離空腸 }\end{array}$ & 両Y字又はU字 & 5 \\
\hline 中咽頭腫瘍 & $\begin{array}{l}\text { 腫瘍摘出+両頸部郭清 } \\
\quad+\text { 前腕皮弁 }\end{array}$ & 両Y字+正中 & 3 \\
\hline 頸部再発 & 両頸部郭清 & U字 & 1 \\
\hline 舌腫瘍 & 舌半側切除+頸部郭清 & Y字 & 1 \\
\hline 喉頭腫瘍 & 喉頭全摘 & T字 & 1 \\
\hline 頸部瘻孔 & 瘻孔閉鎖 & & 1 \\
\hline
\end{tabular}



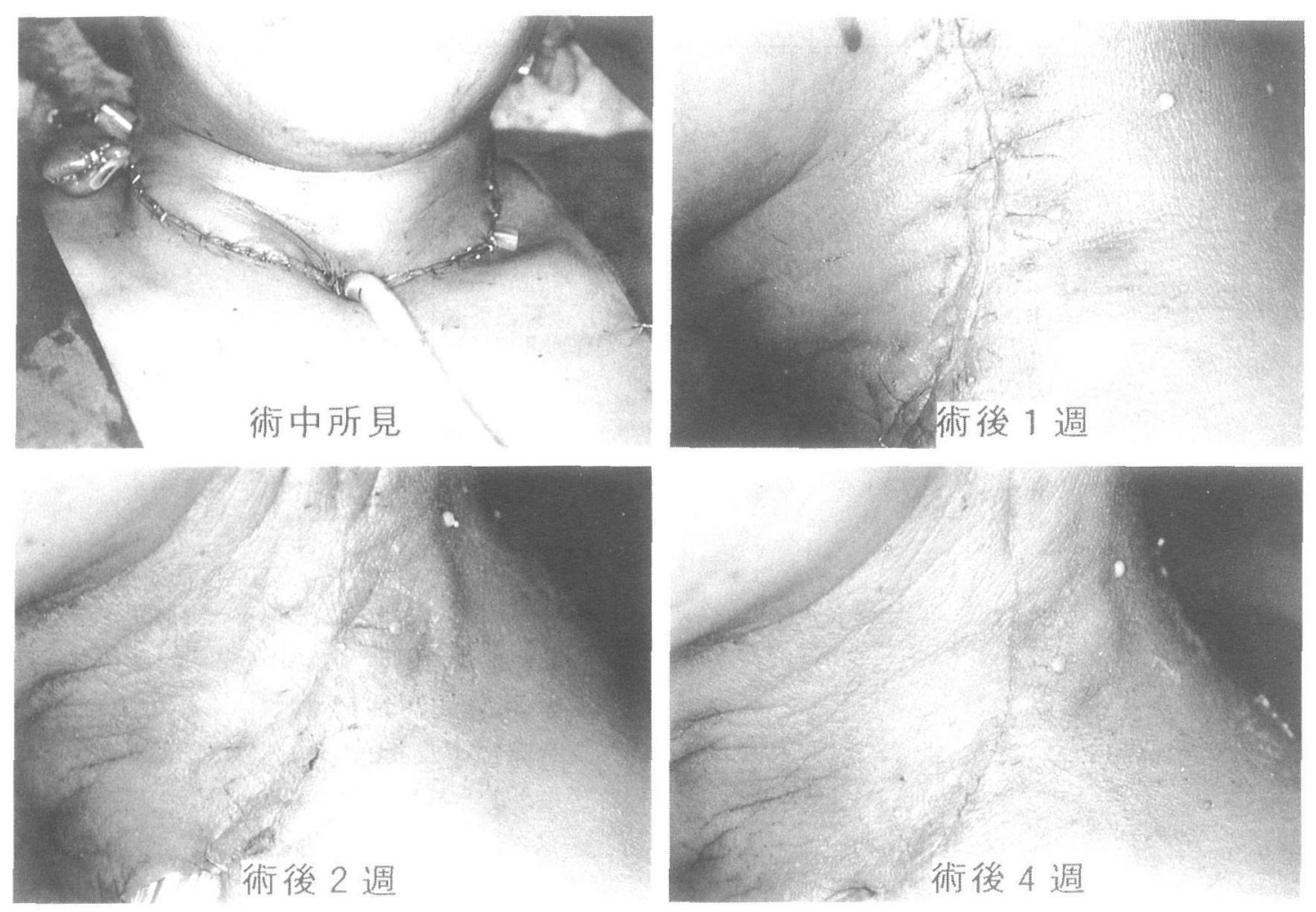

図 2 術中扣よび術後縫合創

術後 4 週ではナイロン系による縫合とほとんど差を認めない.

表 3 術後縫合創の評価

\begin{tabular}{|c|c|c|c|}
\hline $\mathrm{NO}$ & 診 & 手 & 術後縫合創 \\
\hline 1 & 下咽頭腫瘍 & 咽·喉·食摘出+両頸部郭清+遊離空腸 & 良 \\
\hline 2 & 下咽頭腫瘍 & 咽・喉·食摘出+両頸部郭清+遊離空腸 & 良 \\
\hline 3 & 下胭頭腫瘍 & 咽·喉·食摘出+両頸部郭清+遊離空腸 & 良 \\
\hline 4 & 下咽頭腫瘍 & 咽・喉・食摘出+両頸部郭清+遊離空腸 & 良 \\
\hline 5 & 下咽頭腫瘍 & 咽・喉・食摘出+両頸部郭清+遊離空腸 & 良 \\
\hline 6 & 中咽頭腫瘍 & 腫瘍摘出+両頸部郭清+前腕皮弁 & 良 \\
\hline 7 & 中胭頭腫瘍 & 腫瘍摘出+両頸部郭清+前腕皮弁 & 良 \\
\hline 8 & 中咽頭腫瘍 & 腫瘍摘出+両頸部郭清+前腕皮弁 & 良 \\
\hline 9 & 頸部再発 & 両頸部郭清 & 良 \\
\hline 10 & 舌腫瘍 & 舌半側切除+頸部郭清 & 良 \\
\hline 11 & 頸部瘻孔 & 瘻孔閉鎖 & 良 \\
\hline 12 & 喉頭腫瘍 & 喉頭全摘 & 良 \\
\hline
\end{tabular}

の安全面で重要な点は頸部皮膚の厚さである。表 4 に全 症例の頸部皮膚の厚さを示すが，頸部皮膚の厚さ $7 \sim 8$ $\mathrm{mm}$ の症例が多数であった。頸部皮膚の厚さ 7〜8 mm の症例を選び，皮下縫合(約 $1 \mathrm{~cm}$ 間隔) の有無による縫 合創の違いをみた、皮下縫合を行わないでステイプルを 刺入すると, 皮下にステイプルが露出するが(図 3 下段),
皮下縫合後ステイプルを刺入すると，皮下へのステイプ 儿露出は認められなかった(図 3 上段).この結果から通 常の皮下縫合を行えば安全面でも問題ないと考光られる。 今回の対象症例では全例皮下縫合を行い, ステイプルが 原因と考えられるトラブルは1例も認められなかった。 
表 4 頸部皮膚の厚さ

\begin{tabular}{|c|c|c|c|c|}
\hline 年齢 & 性 & 診 & 手 & 皮膚の厚さ \\
\hline 62 & 男 & 頸部瘻孔 & 瘻孔閉鎖 & $10(\mathrm{~mm})$ \\
\hline 57 & 男 & 中咽頭腫瘍 & 腫瘍摘出+両頸部郭清 & 10 \\
\hline 63 & 男 & 中咽頭腫瘍 & 腫瘍摘出+両頸部郭清 & 8 \\
\hline 59 & 男 & 中咽頭腫瘍 & 腫瘍摘出+両頸部郭清 & 8 \\
\hline 79 & 男 & 下咽頭腫瘍 & 咽・喉・食摘出+両頸部郭清 & 8 \\
\hline 64 & 男 & 喉頭腫瘍 & 喉頭全摘 & 8 \\
\hline 61 & 男 & 下咽頭腫瘍 & 咽・喉・食摘出+両頸部郭清 & 8 \\
\hline 76 & 男 & 舌腫瘍 & 舌半側切除+頸部郭清 & 8 \\
\hline 69 & 男 & 頸部再発 & 両頸部郭清 & 7 \\
\hline 52 & 男 & 下咽頭腫瘍 & 咽・喉・食摘出+両頸部郭清 & 7 \\
\hline 53 & 男 & 下咽頭腫瘍 & 咽・喉・食摘出+両頸部郭清 & 7 \\
\hline 44 & 男 & 下咽頭腫瘍 & 咽 - 喉 - 食摘出+両頸部郭清 & 7 \\
\hline
\end{tabular}
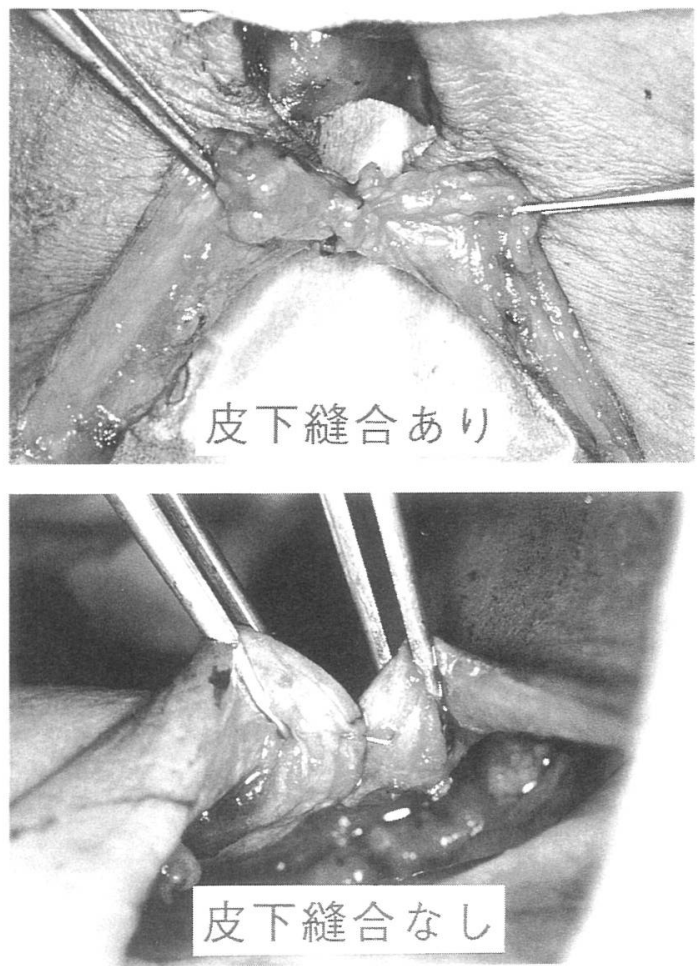

図 3 皮下縫合の有無之皮下所見

「皮下縫合めり」では皮下へのステイプル露出は認 められない。

考察

スキンステイプラーはこれまで主に一般外科や整形外 科領域に括いて用いられている。創の縫合にスキンステ イプラーを用いた場合の利点として多くの著者が縫合時 間の短縮をあげている1) 5)。実験的に感染に対する抵抗
性が検討され，ナイロンや絹糸よりステイプラーが優れ ていると報告されている677)。皮下縫合と皮膚縫合の感 染に対寸る抵抗性の実験に抹いても, 創感染の原因は主 に皮膚縫合(経皮的縫合)にあり，創感染の予防にはテー プが最良であるがステイプルも同等の感染抵抗性がある と述べられている8). 美容面に関しても多くの報告で, ステイプルがナイロンと同等であったといら1) 315)7). 美 容面でナイロンがより優れているとの報告もみられる が9)，この報告に和ける創は殿部や膝部であり，ステイ プラー使用例の創が不良であった原因は術後圧迫や動さ が加わったためと考光られる. 術後強い圧迫や動きが加 わる部位にはステイプルの使用を避けるべきであろら.

頸部は重要な血管や神経があり, 頸部郭清を行った症 例では先れらが皮膚直下に露出するので，特に安全面の 確認が必要である。これまで頭頸部に和けるスキンステ イプラー使用経験の報告が稀で, 日常臨床で用いられて いないのは安全面に対する危惧からであろら。我々の調 べ得た範囲では安全面の報告は法とんどなく，わずかに 岡田ら1)が「骨, 大血管, 内臓などが皮膚直下にあり, 皮膚との間隔が $5 \mathrm{~mm}$ 以上離せないとさ使用すべきでは ない」と述べている。しかしその判断の根拠については 触れていない。安全面の議論のためにはさらにデータの 蓄積が必要であるが，今回の我々の経験からは皮下縫合 を行光ば頸部皮膚の厚さが極端に薄くない限り安全面の 問題はないと考光た。

$$
\text { まとめ }
$$

1. 簡便な皮膚縫合器であるスキンステイプラーの頡 頸部領域への導入を試みた。 
2. 皮膚縫合時間は約 $1 / 10$ に短縮できた。

3. 美容面においても十分に満足できる結果であった。

4. 安全面でも皮下縫合を行えば問題はないと思われ た。

\section{参考文献}

1) 岡田菊三, 野末 洋, 安藤謙一, 他: 新しい創縫合器 “Proximate” の使用経験. 医療 $35: 477 \sim 481,1981$.

2 ) Thompson DP and Ashley FL : Use of the stapler in skin closure. Am J Surg $132:$ 136 138, 1976.

3 ) Mering L, Cillers K, Barry R, et al : A comparison of a disposable skin stapler and nylon sutures for wound closure. S Afr Med J 62 : 371 372, 1982.

4 ) Jones Jr KC, Himel HN, Towler MA, et al : New advances in automatic disposable rotating cartridge skin staplers. Burns $19: 159 \sim 165,1993$.

5 ) Nilsson T, Moller CF and Jeppesen N : Long-term cosmetic results comparing Proximate stapler with dermalon skin closure. Ann Chir Gynaecol $74: 30 \sim 31,1985$.

6 ) Johson A, Rodeheaver GT, Durand LS, et al : Automatic disposable stapling devices for wound closure. Ann Emerg Med $10: 631 \sim 635,1981$.

7 ) Nagamachi $Y:$ Blood flow and tissue reaction at skin wound closures. World J Surg $12: 635 \sim 640,1988$.

8 ) Stillman R, Mario C and Seligman S : Skin staples in potentially contaminated wounds. Arch Surg $119: 821 \sim 822$, 1984.

9 ) Stockly I and Elson R : Skin closure using staples and nylon sutures ; a comparison of results. Ann R Coll Surg Engl 69 : 76 78, 1987.

$\left.\begin{array}{l}\text { 原稿受付: 平成 } 6 \text { 年11月 } 21 \text { 日 } \\ \text { 原稿採択 : 平成 } 7 \text { 年 } 1 \text { 月 } 27 \text { 日 } \\ \text { 別刷請求先 : 今手祐二 } \\ \text { 干7 } 755 \text { 宇部市小串 } 1144 \\ \text { 山口大学医学部耳鼻咽喉科学教室 }\end{array}\right)$

